\title{
Comparative Aspects Of Management Observed By Heads Of Public And Private Schools
}

\author{
Muhammad Imran, UIER, PMAS Arid Agriculture University, Pakistan
}

\begin{abstract}
The major purpose of the research was to compare the managemet aspects in public and private schools. All the heads of secondary schools of public and private sector of the Punjab province, Pakistan constituted population of the study. A sample of 216 head teachers (fifty percent from public sector schools and fifty percent private schools) was selected from nine didtricts. The questionnaire prepared and validated through pilot-testing, was used as the research instrument of the study. The data obtained was tabulated and analyzed by using simple percentage and two way chi square tests. Main conclusions of the study were: that private sector schools had actually less number of students and teachers at secondary level as compared to public sector schools. In public sector schools student-teacher ratio was higher than that of private sector schools. Regarding involvement of subordinate staff in decision making, keeping themselves as a part of team while leading them and carrying out the well-organized tasks, heads of private sector secondary schools were better than heads of public sector secondary schools. The heads of public sector secondary schools were more qualified academically as well as professionally, having more administrative experience as compared to private sector secondary schools' heads.
\end{abstract}

Keywords: Public schools; Private schools; Head teachers; Administrative aspects; Management Aspects.

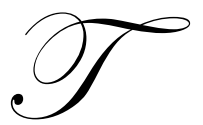

he constitution of Pakistan accepts education as one of the fundamental rights of a citizen as well as constitutional commitment of the government accepts to provide access to education to every citizen (Govt. of Pakistan, 2000). The education system in Pakistan consists of a number of stages, primary, middle secondary, higher secondary and college and university levels (Farooq, 1993). The quality of education is being struggled at all levels in Pakistan alongwith other developing and under developed countries. Students in developing countries have a mean level of achievement below that in industrial countries and their performance shows a much greater variation around the mean (Iqbal, 1987).

Secondary education holds pivotal position in education system, for it is terminal stage for most of students and it also serves as a linkage stage between elementary and higher education. It provides input for higher education and thus quality of higher education is dependant upon secondary education. Secondary education is expected to expand and improve such faculties in the adolescence so that they may play their role as useful citizens of Pakistan (Baloch, 1990). Secondary schools both Middle and High would become multipurpose schools and provide general education with practical bias suited to the interests of the children and the life of the community (Louis, 1987).

There are two sectors working side by side in the field of secondary education, i.e. private sector and government sector in Pakistan (Govt. of Pakistan, 1979). Private sector plays an important role in the development of education in a country. It helps both in the qualitative improvement and the quantities expansion. Private sector bears a good deal of burden of the expenditures on this important social cause even in the most advanced countries. In a country like Pakistan where the population growth rate is about 3 percent, annually and only about 20 percent of the existing children are in the secondary schools, the support of the private sector is the most needed to share this huge burden. Unless education is made free or heavily subsidized it cannot reach the underprivileged sections of society. Government spending has become necessary to update the content and methodology of education. Huge 
governmental financing has become essential to provide new services like guidance and counseling, to give vocational bias to secondary education and to equalize educational expenditure (Maqsoodah, 1998).

Role of head teacher is considered as active driver for better management of schools at any sector. A good head has to perform the role of team leader, supervisor, manager and facilitator to teaching learning environments and also to motivate in case of any deficiency found in system. Edelebosch (1992) states that Educational programmes are more likely to be successful when there is significant community involvement and participation. The school factors considered to be influencing learner achievements are facilities and equipment available in the school, institutional climate and leadership behavior of the head, qualification, training and morale of the teachers (Singhal, 1991).

Although basic minimum infrastructure and qualified teachers are inevitable to improve the quality of secondary education, it cannot be said with certainty by making them available (Satijia, 1998). The standards of education will improve only when these resources are managed well. Improvement of curricula, textbooks and teachers are undoubtedly important inputs to the package of quality improvement, yet the delivery system occupies a far more significant place to make these inputs yield the desired results. In fact, unless the traditional management and delivery system undergo a radical change to suit the needs of the fast expanding secondary education, as also to meet the challenge of inadequacy of resources, there seems to be little hope of raising the quality of secondary education. Good quality education depends on the availability and effective use of (a) teaching methodologies designed to encourage independent thinking; (b) capable, motivated, well-trained teachers; (c) appropriate, welldesigned curriculum; (d) effective learning materials including, but not limited to, textbooks; (e) a suitable, wellmaintained learning environment; and (f) a valid and reliable examination system and a well stocked library as well (Govt. of Pakistan, 1959).

Keeping in view the above circumstances it was imperative to research upon quality of education in Pakistan, especially to compare the management aspects of both the sectors public and private secondary schools. The slogan of the day that quality was deteriorating and lowering in our schools, it was need of the day to observe the head teachers' management as part of quality in schools of public and privately managed. Without improving quality of education, we cannot keep pace with the modern era.

\section{OBJECTIVES OF THE STUDY}

The present study was conducted to compare the quality of education in public and private schools of Punjab having following objectives:

1. To investigate the number and qualification of teachers, the enrolment of students as well as studentteacher ratio in both public and private schools.

2. To compare the administrative, academic, supervisory and support service aspects of management by heads of public and private secondary schools.

3. To make recommendations for improvement of the quality of education in both types of schools.

\section{RESEARCH DESIGN}

As the nature of study was descriptive type. As the population of the study was large, the study was delimited to the secondary schools in public and private sector of the Punjab Province. Punjab province is generally distributed in three zones, which are North Punjab, Central Punjab, and South Punjab. Three districts from each zone were selected randomly. In this way nine districts were selected for the target population.

\section{SAMPLE}

Twenty- four secondary schools (twelve public and twelve private) from each sample district were selected randomly. A total number of two hundred and sixteen head teachers (108 from public sector and 108 from private sector were considered as sample of study. 


\section{PILOT TESTING}

For the pilot testing, a head teacher each from ten secondary schools was taken from district Rawalpindi. The researcher personally visited and administered relevant questionnaire among ten heads. They were requested to give their suggestions freely for the improvement of the questionnaires. They were also requested to amend the questions, if necessary in format and the language to make the questions simple and understandable. Accordingly questionnaires were revised and prepared by incorporating their suggestions and proposals. Then the final version of questionnaire was developed.

\section{DATA ANALYSIS}

Data collected through above-mentioned instrument were tabulated, analyzed and interpreted categorywise. To analyze the data, chi-square as a contingency test and percentage were used.

For statistical treatment chi-square as a contingency test was applied using the following formula:

$$
\begin{aligned}
& O_{i} \quad=\quad \text { Frequency observed or experimental determined } \\
& E_{i} \quad=\quad \text { Frequency expected } \\
& \mathrm{df}=\text { Degree of freedom } \\
& \mathrm{P}=\quad \text { Probability of exceeding the tabulated value of } \mathrm{X}^{2}=O_{i}-E_{i} \\
& \begin{array}{l}
=\quad\left(O_{i}-E_{i}\right)^{2} \\
=\frac{\left(O_{i}-E_{i}\right)^{2}}{E_{i}}
\end{array} \\
& \gamma_{\left(b_{s} s\right.}=\sum \frac{(0-E)^{2}}{2}
\end{aligned}
$$

Chi-square as contingency test was used to compare the frequencies of two groups of heads of public and private schools. The method can be illustrated as follows, using fictional data:

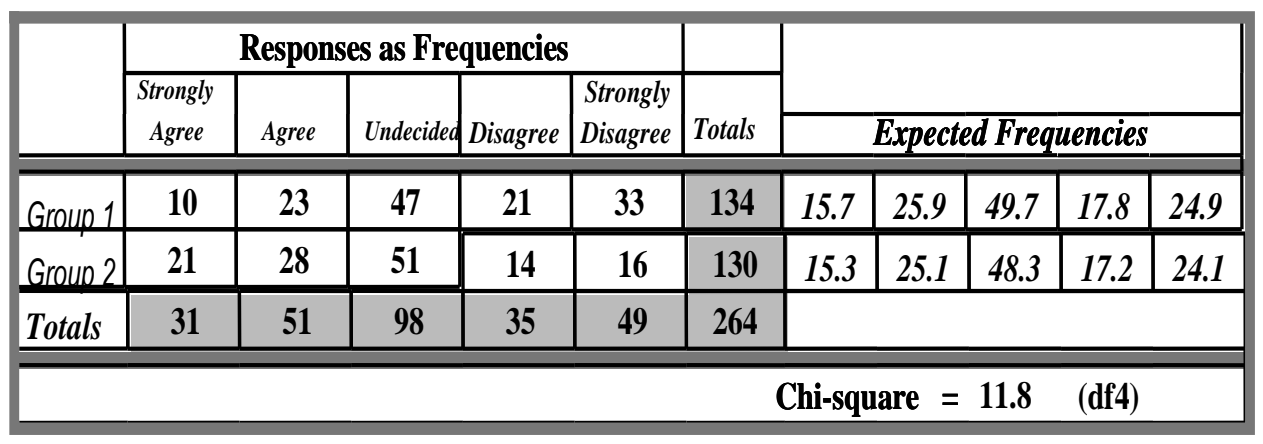

Here there are two samples, neither of which can be regarded as a control group. The samples need not be of the same size. The expected frequencies are found by taking the totals for each of the five choices as the best estimate of the control group and working out what proportion of each sample might be expected to make that choice. Thus, for 'strongly agree', 10 of the sample made that choice with group 1 and 21 with group 2.31 overall made that choice. Thus, the expected frequencies are 15.7 and 15.3 (to the first decimal place). These are obtained as follows:

Group 1 Expected frequency $=31 \times 134 / 264=15.7$

Group 2 Expected frequency $=31 \times 130 / 264=15.3$ 
The value of the degree of freedom for any analysis is obtained from the following calculations:

$\mathrm{df}=(\mathrm{r}-1) \times(\mathrm{c}-1)$

Having seen the significance of difference between two groups by Chi-square as a contingency test, comparing the individual chi square value identified the sources of differences. On the basis of the analysis and interpretation of data, conclusions were drawn and recommendations were made.

\section{RESULTS}

Table 1 (a): Qualification of Administrators and Teachers

\begin{tabular}{|c|c|c|c|c|c|c|c|c|c|c|}
\hline \multirow{2}{*}{\multicolumn{2}{|c|}{ Qualification }} & \multicolumn{5}{|c|}{ Academic } & \multicolumn{4}{|c|}{ Professional } \\
\hline & & Ph.D & M.Phil & $\begin{array}{l}\text { M.A/ } \\
\text { M.Sc }\end{array}$ & $\begin{array}{l}\text { B.A/ } \\
\text { B Sc }\end{array}$ & Others & $\begin{array}{c}\text { M.E } \\
\text { d }\end{array}$ & $\begin{array}{l}\text { B. } \\
\text { Ed }\end{array}$ & C.T & Others \\
\hline \multirow{2}{*}{ Heads } & Public & 02 & 04 & 82 & 20 & 0 & 20 & 88 & 0 & 0 \\
\hline & Private & 0 & 0 & 41 & 49 & 18 & 04 & 55 & 31 & 18 \\
\hline \multirow{2}{*}{ Teacher } & Public & 03 & 10 & 22 & 63 & 10 & 24 & $\overline{52}$ & 12 & 20 \\
\hline & Private & 0 & 02 & 22 & 58 & 26 & 22 & 44 & 16 & 26 \\
\hline
\end{tabular}

Table 1 (b): Enrollment of students in secondary classes and teacher student ratio

\begin{tabular}{|c|c|c|c|c|c|c|}
\hline \multirow[t]{2}{*}{ Sector } & \multirow{2}{*}{$\begin{array}{c}\text { Average } \\
\text { Enrollment }\end{array}$} & \multirow{2}{*}{$\begin{array}{l}\text { Average } \\
\text { teachers }\end{array}$} & \multirow{2}{*}{$\begin{array}{c}\text { Teacher- student } \\
\text { ratio }\end{array}$} & \multicolumn{3}{|c|}{ Nature of Building } \\
\hline & & & & Own & Govt. & Rented \\
\hline Public & 158 & 26 & $1: 70$ & 0 & 98 & 10 \\
\hline Private & 77 & 3 & $1: 28$ & 45 & 0 & 63 \\
\hline
\end{tabular}

The above tables indicate the demographic position of public and privately managed schools. The academic and professional qualifications of both heads and teachers of public sector schools are higher than those of private sector schools. The average enrollment per sampled school of public sector was 158 whereas the average enrollment per sampled school of private sector was 77. Average teacher student ratio in public schools was 1:70 whereas in private schools it was 1:28.

Table 2: Administrative Aspects

\begin{tabular}{||l|l|l|l|l|l|l||}
\hline \multicolumn{1}{|c|}{ Indicators } & School & \multicolumn{3}{|c|}{ Reponses } \\
\hline
\end{tabular}


Table 2 indicates that the $\chi^{2}$ values for all six administrative aspects of public and private schools' head are greater than the critical value at 0.05 level. Involvement of staff in decision making differed significantly in favour of public schools heads in the category of strongly agree. Head's liking to be a part of team with leading teachers differed significantly in favour of private schools heads in the category of strongly agree. The aspect of well organization of tasks was found differed significantly in favour of private schools' heads in the category of strongly disagree. The fair selection procedure for recruitment of teachers differed significantly in favour of public schools. The coordination among the administrative staff differed significantly in favour of private schools' heads in the category of strongly agree. Whereas, the teachers having command over subject matter differed significantly in favour of public schools' heads in the category of strongly agree.

Table 3: Academic Aspects

\begin{tabular}{|l|l|l|l|l|l|l|l|}
\hline \multicolumn{2}{|c|}{ Indicators } & School & \multicolumn{3}{|c|}{ Reponses } \\
\hline
\end{tabular}

Table 3 exhibits that the obtained $\chi^{2}$ value is greater than the critical value at 0.05 level as the frequency of responses of public and private schools' heads about four aspects. Ensuring job security for teachers differed significantly in favour of public schools' heads in the category of strongly agrees. Teachers having command over teaching methodology differed significantly in favour of public schools' heads in the category of strongly agree. Giving attention to the character building of students does not differ significantly. School providing quality education differed significantly in favour of private schools' heads in the category of strongly agrees. Students competing well with other students do not differ significantly. Keeping school's environment suitable for teaching differed significantly in favour of public schools' heads in the category of strongly agree.

Table 4 exhibits that the obtained $\chi^{2}$ value is greater than the critical value at 0.05 level for the frequency of responses of public and private schools' heads about five aspects. Observing timings properly differed significantly in favour of private schools' heads in the category of strongly agree. Arranging sports and games differed significantly in favour of public schools' heads in the category of strongly agree. Relevance of subjects and content being taught to the present and future needs to society does not differ significantly. Adoptions of fair assessment procedure differed significantly in favour of public schools' heads in the category of strongly disagree. Students' admission according to merits differed significantly in favour of public schools' heads in the category of strongly agree. Adequate student -teacher ratio differed significantly in favour of private schools' heads in the category of strongly disagree. 
Table 4: Supervisory Aspects

\begin{tabular}{|c|c|c|c|c|c|c|c|}
\hline \multirow[t]{2}{*}{ Indicators } & \multirow[t]{2}{*}{ School } & \multicolumn{5}{|c|}{ Reponses } & \multirow{2}{*}{$\chi^{2}$} \\
\hline & & $\mathbf{S A}$ & $\mathbf{A}$ & UD & $\overline{\text { DA }}$ & SDA & \\
\hline \multirow{2}{*}{$\begin{array}{l}\text { Timings ore observed } \\
\text { properly }\end{array}$} & Public & 22 & 26 & 3 & 30 & 27 & \multirow[t]{2}{*}{$11.5^{*}$} \\
\hline & Private & 42 & 27 & 2 & 23 & 14 & \\
\hline \multirow{2}{*}{$\begin{array}{l}\text { Sports and games are } \\
\text { arranged }\end{array}$} & Public & 67 & 38 & 2 & 1 & 0 & \multirow[t]{2}{*}{$17.8 *$} \\
\hline & Private & 24 & 18 & 3 & 35 & 28 & \\
\hline \multirow{2}{*}{$\begin{array}{l}\text { Subjects and contents being } \\
\text { taught are relevant to needs to } \\
\text { society. }\end{array}$} & Public & 46 & 35 & 1 & 18 & 8 & \multirow{2}{*}{2.7} \\
\hline & Private & 37 & 34 & 2 & 25 & 10 & \\
\hline \multirow{2}{*}{$\begin{array}{l}\text { The student assessment } \\
\text { procedure is fair }\end{array}$} & Public & 22 & 18 & 2 & 26 & 40 & \multirow[t]{2}{*}{$10.2 *$} \\
\hline & Private & 36 & 16 & 3 & 32 & 21 & \\
\hline \multirow{2}{*}{$\begin{array}{l}\text { Students are admitted } \\
\text { according to merits }\end{array}$} & Public & 42 & 28 & 4 & 22 & 12 & \multirow[t]{2}{*}{$12.9 *$} \\
\hline & Private & 26 & 24 & 1 & 30 & 27 & \\
\hline \multirow{2}{*}{$\begin{array}{l}\text { Student -teacher ratio is } \\
\text { adequate. }\end{array}$} & Public & 18 & 20 & 2 & 30 & 38 & \multirow{2}{*}{$14.0 *$} \\
\hline & Private & 33 & 24 & 3 & 32 & 16 & \\
\hline
\end{tabular}

Table 5: Support Services Aspects

\begin{tabular}{|c|c|c|c|c|c|c|c|}
\hline \multirow[t]{2}{*}{ Indicators } & \multirow[t]{2}{*}{ School } & \multicolumn{5}{|c|}{ Reponses } & \multirow{2}{*}{$\chi^{2}$} \\
\hline & & SA & $\mathbf{A}$ & UD & DA & SDA & \\
\hline \multirow{2}{*}{$\begin{array}{l}\text { Science laboratories are well } \\
\text { equipped }\end{array}$} & Public & 40 & 16 & 5 & 25 & 22 & \multirow[t]{2}{*}{$12.0 *$} \\
\hline & Private & 20 & 14 & 4 & 32 & 38 & \\
\hline \multirow[t]{2}{*}{ Needed A.V. aids are available. } & Public & 36 & 20 & 3 & 26 & 23 & \multirow[t]{2}{*}{$19.2 *$} \\
\hline & Private & 13 & 17 & 2 & 30 & 46 & \\
\hline \multirow{2}{*}{$\begin{array}{l}\text { Sufficient furniture in available in } \\
\text { rooms. }\end{array}$} & Public & 42 & 26 & 2 & 25 & 13 & \multirow{2}{*}{$11.6 *$} \\
\hline & Private & 26 & 24 & 1 & 26 & 31 & \\
\hline \multirow{2}{*}{$\begin{array}{l}\text { The school has separate staffroom } \\
\text { for teachers. }\end{array}$} & Public & 48 & 26 & 2 & 19 & 13 & \multirow{2}{*}{ 11.6* } \\
\hline & Private & 30 & 20 & 2 & 31 & 25 & \\
\hline \multirow{2}{*}{$\begin{array}{l}\text { Drinking water facility is } \\
\text { available. }\end{array}$} & Public & 30 & 32 & 1 & 26 & 19 & \multirow[t]{2}{*}{1.9} \\
\hline & Private & 38 & 30 & 2 & 22 & 16 & \\
\hline \multirow[t]{2}{*}{ Building facility is adequate } & Public & 44 & 28 & 2 & 24 & 10 & \multirow[t]{2}{*}{ 29.5* } \\
\hline & Private & 16 & 20 & 2 & 37 & 33 & \\
\hline
\end{tabular}

Table 5 shows that the obtained $\chi^{2}$ value is greater than the critical value at 0.05 level for the frequency of responses of public and private schools' heads about five aspects. Science laboratories being well equipped differed significantly in favour of public schools' heads in the category of strongly agree. Needed A.V. aids are available differed significantly in favour of public schools' heads in the category of strongly agree. Availability of sufficient furniture in rooms differed significantly in favour of public schools' heads in the category of strongly agree. The school having separate staffroom for teachers differed significantly in favour of public schools' heads in the category of strongly agree. Availability of drinking water facility does not differ significantly. Adequate building facility differed significantly in favour of public schools' heads in the category of strongly agree. 


\section{CONCLUSIONS}

- $\quad$ The demographic data of study revealed that private sector schools had actually less number of students and teachers at secondary level as compared to public sector schools. The results of 10th class students in boards' examinations of private schools were better than government schools. With respect to ownership of building almost 98\% public sector schools had their own buildings while majority of private schools were running in rented buildings. In public schools, student teacher ratio was higher than private schools.

- The quality of education is the most burning issue of the day. Administration is considered to be the most important ingredient of any organization, for it serves as the asset for the most previous assets of the nations which are educational institutions. The entire study revealed that heads of private sector secondary schools were better than heads of public sector secondary schools regarding involvement of other staff in decision making, keeping themselves as a part of team while leading them and carrying out the tasks in a well- organized fashion. But the heads of public sector secondary schools were more qualified academically as well as professionally having more administrative experience as compared to private sector secondary schools' heads.

- It is no more rhetoric but a time tested reality that destiny of the nations is shaped in classrooms. It means that teachers are the central figure in education system of any country. The present research found that teachers of public secondary schools were more qualified academically as well as professionally having command over teaching methodology as compared to the teachers of private secondary schools.

- Head teachers' management aspects were found better in privately managed schools for the aspects of becoming a part of team well arranged tasks, and coordination among administrative staff. Whereas the aspects of involving staff in decision making, keeping selection procedure fair, and observing teachers' command over subject matter were found dominant in public sector schools.

- $\quad$ The quality of education is intrinsically integrated and directly proportional to the quality of infrastructure. The physical facilities hold paramount position in educational institutions. It was found that position of physical facilities was better in public secondary schools than in private secondary schools with respect to buildings, libraries, play grounds, furniture while position of private sector secondary schools was better in availability of computer labs and gas facilities.

- $\quad$ The quality of education also owes a lot to the quality of supervision. It was found head teachers of private schools were better for having observing timing, and maintaining teacher student ratio. Whereas arranging sports and game, keeping fair assessment procedure and merit based admission were found dominant at public sector schools' management.

\section{RECOMMENDATIONS}

The enrollment of students was higher in public sector than private sector. It is therefore recommended to establish more schools in the public sector. School mapping kept in mind before establishing new schools. The heads and teachers of schools should take such necessary actions which may help to raise academic standard of these schools. The heads of public schools should take serious consideration of the problem of their low pass percentage. Teachers of public schools may be made accountable for their poor result in examinations. They must also be rewarded with incentives for showing good results. Teachers of both systems should be given opportunities for regular in-service training in order to improve their teaching methodology. Libraries of public and private schools should be kept well maintained and all necessary books be available and students and teachers should be encouraged to get benefit from their library. All necessary educational facilities such as well maintained buildings; science laboratories with standardized apparatus and needed audio visual aids be provided and maintained by school management. Teachers should be encouraged to make use of A.V. aids more and more to make teaching process more effective. The school curriculum should be updated according to the emerging needs of the society and it should be revised regularly. The study indicates that due consideration was not given to merit in student admission procedure. Merit should be the sole consideration for entry to private institutions. Access to higher education, is recommended to base on entry tests that measure the aptitude and ability of suitable candidates for higher learning. The services of National Testing Service be utilized for construction of valid and reliable tests at secondary level. 


\section{DISCUSSION}

Pakistan needs to develop a good strategy of human development in which good quality education, adaptation and skill acquisition are given the primary importance (Shah, 2007). Secondary education is the anchor bay of education. It holds pivotal position in entire education system. It provides middle level work force for the economy and on the other hand it acts as an input for higher education. This study manifested that public sector secondary schools were better than that of private sector secondary schools regarding infrastructure. Quality of management has a central role in secondary education. It has remained neglected for long and it is time that it now receives special attention. But obviously, it would necessitate a new look at some of the basic issues relating to policy, planning and management of secondary education, especially in the third world countries. In western countries private sector schools are much better than public schools (Singhal, 1991). This study contrasted with the above mentioned results of the study conducted by Singhal (1991) as in our country heads of public sector secondary schools were highly qualified academically as well as professionally having more experience as compared to heads of private sector secondary schools.

The situation in Pakistan's secondary schools falls short in most aspects. Teaching is almost entirely in the lecture/recitation mode. Teachers are often poorly motivated and have few opportunities to keep themselves up-todate in content or methodology; curriculum is outdated and poorly disseminated; textbooks do not match curriculum objectives, are badly organized, are of low production quality; learning materials, except for textbooks, are scare; and examinations are technically flawed and their credibility is undermined by widespread cheating and other malpractices. Only motivated trained teachers can make the teaching learning process effective and meaningful. Proper training can motivate the teachers and enhance their performance (Hussain, 2003). Proper physical facilities are necessary for creating conducive environment for teaching learning process. The study showed that position of public sector schools was better than that of private sector secondary schools regarding physical facilities. A study has identified school and family background factors affecting learner achievement. The school factors considered to be influencing learner achievements are facilities and equipment available in the school, institutional climate and leadership behavior of the head, qualification, training and morale of the teachers (Singhal, 1991).

Khaliq (2000) proposed that library services, laboratory services, provision of instructional and furniture, curricula activities, quality of results of inter classes, providing complete teaching staff, co-operation from community, teacher's commitment towards professional obligations, provision of funds, grants and proper physical facilities, supervisory system, motivational and professional training of teaching staff as helpful administrative for quality education. Present study also confirms the same aspects at secondary level. If the heads of institutions should be able to tackle all these problems in their intuitions, they can impart quality education at higher secondary level. In a report on the examination system Deakin (1974) found the public examination system of Pakistan in a state of near anarchy. Private managed schools have some limitations also, the shortage of physical facilities lies in such limitations but along with all such, their proper management produces good results. The both sector must utilize the dominant aspects in their own circumstances.

\section{AUTHOR INFORMATION}

Muhammad Imran is presently Ph.D. scholar in the University Institute of Education and Research, Pir Mehr Ali Shah Arid Agriculture University, Rawalpindi, Pakistan.

\section{REFERENCES}

1. Baloch, F. M. and S. A. Khalid. 1990. Secondary Education in Balochistan. Provincial Education Council, Quetta, Pakistan.

2. Deakin, J. 1974. A Report on Public Examinations in Pakistan. Ministry of Education, Islamabad, Pakistan.

3. Edelenbosch, J. 1992. Community Involvement in Educational Process. McGraw Hill Book Company New York, USA.

4. Farooq, R.A. 1993. Education System in Pakistan. Asia Society for Promotion of Innovation and Reform in Education, Islamabad.

5. Govt. of Pakistan. 1959. Report of the Commission on National Education. Karachi. pp. 144-145. 
6. Govt. of Pakistan. 1979. National Education Policy. Ministry of Education Islamabad. P-32.

7. Govt. of Pakistan. 2000. Economic Survey of Pakistan 1999-2000. Economic Advisor's Wing, Finance Division, Islamabad. P. 117, 139.

8. Hussain, S. 2003. Provisions for Education in Five Year Plans Iqbal Open University Printing Press, Islamabad, Pakistan. pp. 103-148.

9. Iqbal, M. 1987. Review of Educational Policies. Punjab Education Extension Center. Lahore. P. 22 , 30.

10. Khaliq, H.A. 2000. A Study of the Administrative Problems of Boys Higher Secondary Schools in Pakistan. Ph.D. Unpublished Thesis IER. University of Punjab, Lahore.

11. Louis, D. H. 1987. The Crises of Education in Pakistan. Royal Book Company Karachi, Pakistan.

12. Maqsoodah, A. 1998. Role of Private sector in Expansion of Primary Education in Rawalpindi City. Department of Educational Planning and Management, Allama Iqbal Open University, Islamabad:. Unpublished M.A. Thesis.

13. Satijia, B. R. 1998. Value Education Trends in Education. Anmol Publication, Pvt. Ltd. New Delhi, India. 14. Shah, R. (2007) Impact of Higher Education on Earnings of Women in the Public Sector Educational Institutions in Pakistan. International Business \& Economics Research Journal. 6(11)121-122

15. Singhal, R. P. 1991. Education and Training in Sri Lanka. Asian Development Bank and Edcil. 


\section{NOTES}

